\title{
Epigyne or epigynum: what is correct?
}

\section{Как правимьно: еріgуnе или еріgynum?}

\author{
Yuri M. Marusik \\ Ю.М. Марусик
}

Institute for Biological Problems of the North RAS, Portovaya Str.18, Magadan, 685000 Russia. E-mail: yurmar@mail.ru Department of Zoology \& Entomology, University of the Free State, Bloemfontein 9300, South Africa

Институт биологических проблем Севера ДВО РАН, Портовая 18, Магадан 685000 Россия.

KEY WORDS: Aranei, epiandrus, epiandrum, epigaster, epigastrum, etymology, spider, terminology.

КЛЮЧЕВЫЕ СЛОВА: Aranei, epiandrus, epiandrum, epigaster, epigastrum, паук, терминология, этимология.

ABSTRACT. Etymology of three terms used in spider morphology (epigyne, epigaster and epiandrus), and their spelling are discussed. The term "epigyne" was first introduced by Savigny \& Audouin in 1826, but not by Walckenaer in 1837 , as previously thought.

How to cite this paper: Marusik Yu.M. 2021. Epigyne or epigynum: what is correct? // Arthropoda Selecta. Vol.30. No.1. P.130-132. doi: 10.15298/arthsel. 30.1 .13

РЕЗЮМЕ. Дана этимология трёх терминов, используемых в арахнологическое терминологии: epigyne, epigaster и epiandrus. Обсуждаются их разные варианты написания. Установлено, что термин epigyne был впервые предложен Savigny \& Audouin в 1826, а не Валкенером [Walckenaer, 1837] как считалось ранее.

\section{Introduction}

In editing, reviewing, and writing numerous taxonomic papers on spiders, I found several instances in which the same anatomical term in English was used with a different ending, e.g.: epigyne vs. epigynum, epigaster vs. epigastrum, and even spermatheca vs. spermathecum. The word "epigyne" is used as an English word (plural, epigynes), while "epigynum" predominately is used as a Latin word (plural, epigyna). Both versions are commonly used.

The main trigger for this contribution was the demand of the editors in several taxonomic journals for uniformity and for using exclusively the "epigynum" as a Latin word.

To understand the origin of the abovementioned terms and their usage, I have attempted to search all major literature sources since Clerck [1757] to find the first usage and the author of specific terms, with their original meaning. The terminology of the female copulatory organs was discussed by Engelhardt [1909]. The history of study of both the male palp and the female epigyne is given in brief in Blauvelt [1936], and in more detail in Gering [1953]. Since Gering's survey [1953], none of the modern textbooks (e.g. DippenaarSchoeman, Jocqué, 1997; Deeleman-Reinhold, 2001; Ubick et al., 2005; Jocqué, Dippenaar-Schoeman, 2006) or papers that cover spider morphology address the etymology of the copulatory organ structures. Furthermore, while examining the history of the terminology, I realized that there are no data on who first used certain terms, such as vulva, spermatheca, epigyne, and endogyne. The goals of this paper were to determine: (1) who were the first authors to introduce the term "epigyne/epigynum", and (2) what is the correct spelling of this term, as well as two other terms: "epiandrus" and "epigaster".

\section{Methods}

All major publications dealing with spiders since Clerck [1757] were searched. Most of publications were found in the WSC [2021], and some in the Biodiversity Heritage Library (https://www. biodiversitylibrary.org/). While discussing modern usage of the terms, I tried to refer first of all to wellknown authorities in arachnology.

\section{Discussion}

\section{Epigyne vs epigynum}

ETYMOLOGY: from Greek words "epi-" (above) and "gyne" (female, or female sexual organ). Gender feminine both in Latin and Greek.

In the survey of history of terminology used for spider copulatory organs Gering [1953: 36] thought that this term (spelled in Gering as "epigynum") was first invented by Walckenaer [1837]. However, I found that it was used first used by Savigny \& Audouin [1826: 6] in French as: "l"épigyne, organe prévulvaire". Walckenaer [1837: 88-89] was aware of the term and mentioned that he "prefers the term oviduct instead of the earlier proposed term epigyne". This term has been 
used in Latin, French, German, and English texts. Tullgren [1946] used "epigyn" in Swedish. It appears that in all European languages, "epigyne" is considered a word of a native vocabulary rather than a Latinized Greek word. In English texts, European authors consider this term an English word and pluralize it as "epigynes".

The same term spelled as "epigynum" likely was first used by the Austro-Hungarian arachnologist Herman [1868] in a German text. It is unclear if Herman considered it a German or Latin word. Next, "epigynum" was used by Emerton [1875], and all North American arachnologists until recently have followed this spelling, considering it to be a Latin word (i.e., plural "epigyna"). Currently, "epigynum" is used by almost all North and South American authors, and a few European, Asian, and African authors. Today, some authors are also using "epigynum" as an American English word and pluralize it as "epigynums" [Dondale et al., 2003; Gordh, Headrick, 2011; Meriam Webster, 2019]. Some authors, for example Ramírez [2014] and Ramírez et al. [2019] are using in the same text both "epigynum" and "epigyne" as well as "female genitalia, ventral". "Epigynum" is used as both a noun and an adjective, whereas the English adjective form of "epigyne" is "epigynal" (e.g., epigynum lobes and epigynal lobes).

It seems that Emerton was not keen in Latin, and thought that all terms should be in the neuter gender, while both Latin and Greek are gender sensitive. Indeed "epigynum" can be used as a word of the American English vocabulary (plural epigynums); however, it is against the rules to change Latin grammar arbitrarily.

\section{Epiandrus vs epiandrum}

ETYMOLOGY: from Greek “epi-” (above) and "andrus" (male), the gender is masculine.

This term refers to the ventral part of male abdomen where gonopore is located.

I have not searched for the origins of this term, but it seems that the word "epiandrum" was invented by someone who was not good in Latin grammar and transformed masculine gender to the neuter. "Epiandrum" is suggested by the "Spider Anatomy Ontology' (http://purl.obolibrary.org/obo/SPD_0000030). It is also commonly used in mite morphology. Like with "epigynum", this term can be use as a word of English vocabulary, but not as Latin.

\section{Epigaster vs epigastrum}

ETYMOLOGY: from Greek "epi-" (above) and “ gaster", the gender is feminine (although in botany most genera ending in "-gaster" are masculine, according to their epithets [http://www.mobot.org/mobot/latindict/keyDetail.aspx?keyWord=gaster]).

This term refers in arachnids to the ventral part of abdomen lying anteriorly from epigastric furrow. It has two incorrect emendations: "epigastrum" [Zyuzin, 1993; Marusik, 2017; Zonstein, Marusik, 2017] or "epigas- trium" [Goloboff, 1995], both of the neuter gender. Both "epigastrum" and "epigastrium" are also used in medicine and entomology. If to use this word as Latin, the correct spelling should be epigaster.

\section{Conclusions}

My general suggestions are to use words that are shorter and treat them as English rather than Latin words. In case if an author prefers to treat popular terms as Latin words, they should strictly follow rules of Latin grammar.

Acknowledgements. I thank the following colleagues for the comments on this the earlier draft of this manuscript: Sarah Crews (San Francisco, USA), Mykola M. Kovblyuk and Anton A. Nadolny (Ukraine), Alireza Zamani and Seppo Koponen (Turku, Finland), Martin J. Ramírez (Buenos Aires, Argentina), Victor Ya. Fet (West Virginia, USA).

\section{References}

Blauvelt H.H. 1936. The comparative morphology of the secondary sexual organs of Linyphia and some related genera, including a revision of the group // Festschrift Embrik Strand. Riga. Bd.2. P.81-171.

Clerck C. 1757. Svenska spindlar, uti sina hufvud-slågter indelte samt under några och sextio särskildte arter beskrefne och med illuminerade figurer uplyste. Stockholmiae. $154 \mathrm{pp}$.

Deeleman-Reinhold C.L. 2001. Forest spiders of South East Asia: with a revision of the sac and ground spiders (Araneae: Clubionidae, Corinnidae, Liocranidae, Gnaphosidae, Prodidomidae and Trochanterriidae). Leiden: Brill. 591 pp.

Dippenaar-Schoeman A.S., Jocqué R. 1997. African Spiders: An Identification Manual // Plant Protection Research Institute Handbook. Vol.9. 392 pp.

Dondale C.D., Redner J.H., Paquin P., Levi H.W. 2003. The insects and arachnids of Canada. Part 23. The orb-weaving spiders of Canada and Alaska (Araneae: Uloboridae, Tetragnathidae, Araneidae, Theridiosomatidae). Ottawa: NRC Research Press. 371 pp.

Emerton J.H. 1875. Notes on spiders from Caves in Kentucky, Virginia and Indiana // American Naturalist. Vol.9. P.278281 .

Engelhardt V. 1910. Beiträge zur Kenntnis der weiblichen Copulationsorgane einiger Spinnen // Zeitschrift für Wissenschaftliche Zoologie. Bd.96. S.32-117.

Gering R.L. 1953. Structure and function of the genitalia in some American agelenid spiders // Smithsonian Miscellaneous Collections. Vol.121. No.4. P.1-84.

Goloboff P.A. 1995. A revision of the South American spiders of the family Nemesiidae (Araneae, Mygalomorphae). Part I: species from Peru, Chile, Argentina, and Uruguay. Bulletin of the American Museum of Natural History. Vol.224. P.1-189.

Gordh G., Headrick D.H. 2011. A Dictionary of Entomology. Second Edition. Abingdon, Oxfordshire, UK: CABI and Marston Book Services Ltd. 1536 pp.

Herman O. 1868. Über das Sexualorgan der Epë̈ra quadrata Walck. // Verhandlungen der Kaiserlich-Königlichen ZoologischBotanischen Gesellschaft in Wien. Bd.18. S.923-930.

Jocqué R., Dippenaar-Schoeman A.S. 2006. Spider families of the world. Tervuren: Musée Royal de 1'Afrique Central. 336 pp.

Marusik Yu.M. 2017. Redescription of the type species of the genus Argistes (Aranei, Liocranidae) // Vestnik Zoologii. Vol.51. No.5. P.363-368.

Merriam Webster dictionary. 2021. https://www.merriam-webster. com/dictionary/dictionary 
Ramírez M.J. 2014. The morphology and phylogeny of dionychan spiders (Araneae: Araneomorphae) // Bulletin of the American Museum of Natural History. Vol.390. P.1-374.

Ramírez M.J., Grismado C.J., Ubick D., Ovtcharenko V.I., Cushing P.E., Platnick N.I., Wheeler W.C., Prendini L., Crowley L.M., Horner N.V. 2019. Myrmecicultoridae, a new family of myrmecophilic spiders from the Chihuahuan Desert (Araneae, Entelegynae) // American Museum Novitates. No.3930. P.1-24.

Savigny J.C., Audouin V. 1826. Explication sommaire des planches d'arachnides de l'Égypte et de la Syrie // Description de l'Égypte, ou recueil des observations et des recherches qui ont été faites en Égypte pendant l'expédition de l'armée française, publié par les ordres de sa Majesté l'Empereur Napoléon le Grand. Histoire Naturelle. Vol.1. No.4. P.1-339.

Tullgren A. 1946. Svenska spindelfauna: 3. Egentliga spindlar. Araneae. Fam. 5-7. Clubionidae, Zoridae och Gnaphosidae. Stockholm: Entomologiska Föreningen. $141 \mathrm{~S}$.
Ubick D., Paquin P., Cushing P.E., Roth V. 2005. Spiders of North America: an identification manual. American Arachnological Society. $377 \mathrm{pp}$.

Walckenaer C.A. 1837. Histoire naturelle des insectes. Vol.1. Aptères. Paris. P.1-682.

WSC. 2021. World Spider Catalog. Version 22.0. Natural History Museum Bern, online at http://wsc.nmbe.ch, accessed on March 5, 2021. https://doi.org/10.24436/2

Zonstein S.L., Marusik Yu.M. 2017. Descriptions of the two-eyed African spider genera Chedimanops gen. n. and Hybosidella gen. n. (Araneae, Palpimanidae, Chediminae) // African Invertebrates. Vol.58. No.1. P.23-47.

Zyuzin A.A. 1993. Studies on the wolf spiders (Araneae. Lycosidae). I, A new genus and new species from Kazakhstan, with comments on the Lycosinae // Memoirs of the Queensland Museum. Vol.33. No.2. P.693-700.

Responsible editor K.G. Mikhaiov 